\title{
Holmes, Peirce and Legal Pragmatism
}

In 1881 Oliver Wendell Holmes, Jr., published The Common Law, a revision of a series of lectures he had given at the Lowell Institute in Boston in November and December of $1880 .{ }^{1}$ In The Common Law Holmes aimed at providing a "general view" of the common law, a coherent account of criminal and civil liability. ${ }^{2}$ The central theme of Holmes's theory is that the common law has come to impose liability without regard to the personal moral culpability of the offender. ${ }^{3}$

The Common Law changed the shape of American law. ${ }^{4}$ Professor Grant Gilmore has written that Holmes was not "in the least" interested in describing the common law accurately; Holmes's doctrines were revolutionary, and "[w] hat Holmes told the young lawyers who flocked to his lectures ... promptly became the truth-the indisputable truthof the matter for his own and succeeding generations." Holmes himself, writing about The Common Law 27 years after its publication recognized that "the theories and points of view that were new in it, now have become familiar to the masters and even to the middlemen and distributors of ideas-writers of textbooks and practical works ...." Holmes's emphasis on experience rather than logic, his insistence that law is constantly changing, not static, and his arrangement of the law into crime, tort, and contract has had an important impact on American law. ${ }^{7}$

Holmes's ideas in The Common Law are generally recognized to have been a confluence of his own massive learning, ${ }^{8}$ Nicholas St.John

1. O.W. Holmes, JR., The Common LAw (M. Howe ed. 1963) thereinafter cited as HoLMEs]. For a description of Holmes's lecture series at the Lowell Institute, see $2 \mathrm{M}$. Howe, Justice Oliver Wendell Holmes: The Proving Years 136 nn.2-3 (1963) [hereinafter cited as 2 HowE]. The Common Law is Holmes's only systematic exposition of his legal theory; aside from several legal articles, e.g., Privilege, Malice, and Intent, 8 Harv. L. Rev. 1 (1894), reprinted in O.W. Holmes, Coldected Legal Papers 117 (1920) [hereinafter cited as Collected Papers]. Holmes's writing after 1881 was confined to judicial opinions, commencement addresses, and personal correspondence. See, e.g., On Receiving The Degree of Docton of Laws, in Collected PAPERs, supra, at 33; Holmes-Laski LetTers (M. Howe ed. 1953).

2. HOLMES 5 .

3. See Howe, Introduction to Holmes at $\mathrm{xxi}$.

4. 2 Howe, supra note 1 , at 245-47.

5. G. Gilmore, The DeATH of Contract 21 (1974).

6. Quoted in Howe, supra note 3 , at xi.

7 . Holmes was perhaps the first jurist to devise theories of tort and contract as distinct fields of law. G. Gilmore, supra note 5, at 5-14. Holmes's earliest legal articles deal with the division of the law into the proper categories. Holmes, The Arrangement of the Law -Privity, 7 Am. L. Rev. 46 (1872); Holmes, Codes, and the Arrangement of the Law, 5 AM, L. REv. 1 (1870). See 2 HowE, supra note 1, at 61-95.

8. See 2 Howe, supra note 1, at 135-95; Howe, O.W. Holmes, Jr-Counsellor-at-Law, in Brandeis Lawyer's Soc'y Pub, No. 10 (1948). 
Green's legal writings, ${ }^{9}$ and Chauncey Wright's philosophy. ${ }^{10}$ Yet there are striking logical parallels between The Common Law and the philosophy of Charles Peirce, ${ }^{11}$ the eminent American philosopher and acquaintance of Holmes in the 1860's and 1870's, that have gone unrecognized. ${ }^{12}$ These logical parallels are important for understanding Holmes's legal pragmatism and hence important for understanding our legal history.

Holmes is often called a legal pragmatist on the basis of his "prediction theory" and his emphasis on experience in the evolution of law. ${ }^{13}$ Yet the thread of his pragmatism runs much deeper, and recognition of the pragmatic elements of his legal theory is vital for an

9. Nicholas St. John Green (1835-1868), American lawyer and friend of Holmes. Green's obscurity is due probably to his early death, because his published works are exceptionally prescient, though few in number. N. GREEN, EsSAys on TORT AND CRIME (1933). For a description of Green's legal thought, see P. WIENER, Evolution AND THE FoundERS OF Pragmatism 152-71 (1949). Jerome Frank has argued that Green influenced Holmes's most distinctive legal contributions. Frank, $A$ Conflict With Oblivion: Some Observations on the Founders of Legal Pragmatism, 9 Rurgers L. REv. 425 (1954).

10. Chauncey Wright (1830-1875), American philosopher and friend of Holmes. For a description of Wright's philosophy, see P. WIENER, supra note 9, at 31-70. In 1923 Holmes wrote Morris Cohen, "That we could not assert necessity of the order of the universe I learned to believe from Chauncey Wright long ago." Holmes-CoHEN CoRrespondencE, 34-35 (F. Cohen ed. 1948) (letter of Sept. 14, 1923).

11. Charles Sanders Peirce (1839-1914), American philosopher. Son of Benjamin Peirce, one of America's foremost mathematicians, Peirce has exercised enormous influence on 20th century philosophy. Most of Peirce's adult life was spent with the U.S. Coast and Geodetic Survey, for whom he published his only book to appear in his lifetime, PHoroMETRIC RESEARCHEs (1878). The book won Peirce international recognition among astrophysicists. Peirce taught at Harvard and Johns Hopkins for a total of eight years, but his eccentric personality made formal academic life impossible for him. His last 30 years were spent in penurious seclusion in Milford, Pennsylvania. See Young, Charles Sanders Peirce 1839-1914, in Studies in the Philosophy of Charles Sanders Peirce 271 (P. Wiener \& F. Young eds. 1952); Weiss, Biography of Charles $S$. Peirce, in Perspectives on PeIRCE 1 (R. Bernstein ed. 1965). For Peirce's influence on the British logicians F.P. Ramsey and Lord Russell and on the Austrian philosopher Ludwig Wittgenstein, see H. THAYER, Meaning AND Action 304-13 (1968). Arthur O. Lovejoy, the intellectual historian, has said:

Peirce seems to me to have been the most original and perhaps the most seminal mind among American philosophers of the nineteenth century, and he had, probably, the widest range, "went into" the greatest number of philosophical fields and problems, though often more suggestively than thoroughly.

Quoted in Young, supra, at 274-75. The most useful summary of Peirce's philosophy is W. Gallie, Peirce and Pragmatism (1952). ("Peirce" is inexplicably pronounced "purse." See Am. Heritage Dictionary 967 (1969).)

12. Mark DeWolfe Howe and H.S. Thayer agree that there is little or no direct connection between Holmes's legal theory and Peirce's philosophy. 2 Howe, supra note 1, at 75; H. THAYER, supra note 11, at vifi. Max Fisch thinks Holmes's general outlook was much closer to Peirce's than to William James's, but finds the similarities in Holmes's "prediction theory" of law. Fisch, Justice Holmes, The Prediction Theory of Law, and Pragmatism, 39 J. PHIL. 85 (1942). Philip Wiener also sees Holmes's pragmatism expressed mainly in the prediction theory. P. WIENER, supra note 9 , at 172-89.

The prediction theory is not developed in The Common Law; on the prediction theory, see Holmes, The Path of the Law, 10 HARv. L. REv. 457 (1897), reprinted in Collecred PAPERs, supra note 1, at 167. Other articles describing Holmes's pragmatism do so in only general terms. See, e.g., Brody, The Pragmatic Naturalism of Mr. Justice Holmes, 46 ChI.-Kent L. Rev. 9 (1969); Gregg, The Pragmatism of Mr. Justice Holmes, 31 Geo. L.J. 262 (1943).

13. See note 12 supra. 
understanding of The Common Law. Holmes is a legal pragmatist because he treats rules and standards as necessarily communal and objective, and because he describes the legislative function performed by the community in determining and applying law. These notions are fundamentally Peircian.

Holmes and Peirce were members of a small "Metaphysical Club" that met in Boston and Cambridge between 1870 and $1874 .{ }^{14}$ Other members included William James, Chauncey Wright, and Nicholas St. John Green. ${ }^{15}$ The first mention of this Club is in an 1868 letter from James to Holmes: "When I get home let's establish a philosophical society to have regular meetings and discuss none but the very tallest and broadest questions-to be composed of none but the very topmost cream of Boston manhood."16 In 1907 Peirce wrote:

It was in the earliest seventies that a knot of us young men in Old Cambridge, calling ourselves, half-ironically, half-defiantly, "The Metaphysical Club," . . . used to meet, sometimes in my study, sometimes in that of William James. It may be that some of our old-time confederates would today not care to have such wild-oats-sowing made public . . . . Mr. Justice Holmes, however, will not, I believe, take it ill that we are proud to remember his membership .... [L]est the club should be dissolved, without leaving any material souvenir behind, I drew up a little paper expressing some of the opinions that I had been urging all along under the name of pragmatism. ${ }^{17}$

Peirce's souvenir, read to the Metaphysical Club in November 1872,18 became the celebrated articles, "The Fixation of Belief" and "How To Make Our Ideas Clear."19 Thus Holmes and Peirce may have influenced each other's thought in the early 1870 's. ${ }^{20}$

14. 5 G. Peirce, Collected Papers đ 5.12 (C. Hartshorne \& P. Weiss eds. 1960) [hereinafter cited as PEIRCE]. For further descriptions of the Metaphysical Club, see P. Wiener, supra note 9, at 18-30; Fisch, Was There a Metaphysical Club in Cambridge?, in Studies in the Philosorhy of Charles Sanders Peirce, Second Series 3 (E. Moore ed. 1964).

15. Fisch, supra note 14 .

16. Quoted in Fisch, supra note 14 , at 4.

17. PEIRCE !ा 5.12-.13.

18. Fisch, supra note 14 , at 6 .

19. PeIRCE IT 5.358-.410. These articles were originally published in the November 1877 and January 1878 issues, respectively, of the Popular Science Monthly.

20. In 1920 Holmes wrote to Morris Cohen that he had not heard of pragmatism as late as 1891. Holmes-Conen Correstondence, supra note 10 , at 19 (letter of July 21, 1920). In 1927 Holmes wrote to an editor of Peirce's papers, Charles Hartshorne, "I think I learned more from Chauncey Wright and St. John Green, as I saw Peirce very little." Quoted in Fisch, Alexander Bain and the Genealogy of Pragmatism, $15 \mathrm{~J}$. Hist. of IDEAs 413, 414 n.6 (1954). There is no record that Holmes read any of Peirce's articles until 1923 when he read the collection entitled Chance, Love and Logic. See HoLMEs-CoHEN Correspondence, supra note 10, at 34 (letter of Sept. 14, 1923). Certainly Holmes and Peirce would not have been attracted to each other as young men: Holmes was a proper 
Philip Wiener has said of the Metaphysical Club: "There is scarcely any basic problem in the natural and social sciences to which this group did not make some important contribution to our thinking."21 Holmes and Peirce as members of the Metaphysical Club were part of a conceptual revolution in American thought that rejected individualism and shifted toward collectivism in epistemology, science, and law. In The Common Law this revolution was expressed as an attack on a conception of legal rules as private, internal, and subjective. In Peirce's early philosophy this revolution was expressed as an attack on the epistemology of Rene Descartes, the 17th century French philosopher.

This conceptual revolution provides the intellectual setting for an examination of three fundamental parallels between The Common Law and Peirce's early philosophy: first, the attack on private and internal standards; second, the insistence that objective standards can only result from intersubjective agreement among members of a community; and finally, the postulation that the processes of inquiry and adjudication will continue indefinitely.

\section{External Standards in Holmes and Peirce}

Mark DeWolfe Howe, Holmes's biographer, has described Holmes's intellectual aims in the years before he wrote The Common Law:

In 1872 he [Holmes] was not, I think, seriously searching for a jurisprudence consistent with the philosophical premises of his generation. He was neither considering the nature of truth nor twisting the tail of the cosmos. He was engaged in the more limited and quite hard-headed task of examining the validity of Austin's thesis that law is always identifiable as the command of the sovereign. ${ }^{22}$

The result of Holmes's task was in fact a theory of law opposed to Austin's. For Austin the will of the sovereign is utterly unbounded; the sovereign issues commands in accordance with standards that are

Bostonian, a Civil War hero, while Peirce was a young genius, as difficult to get along with as a "snarl of twine." Still, it is clear that Holmes's general outlook closely resembled Peirce's. See Fisch, supra note 12, at 96 n.27. Fisch suggests Holmes lost touch with Peirce and came to associate "pragmatism" with the philosophy of William James. Id. at 96. Together with Holmes's general reluctance to acknowledge intellectual indebtedness, see 2 Howe, supra note 1 , at $71-72,84$, this may account for Holmes's neglect of Peirce in later years.

21. P. WIENER, supra note 9 , at v.

22. 2 Howe, supra note 1 , at 75 . See generally J. Austin, The Province of JurisPRUDENCE DETERMINED (1954). 
personal and independent of the will of any other individual. Although the sovereign may defer to the wishes of his subjects, he need not. The sovereign's legislation is judged only by the sovereign's standards. The Common Law, on the other hand, takes the "felt necessities of the time, the prevalent moral and political theories, intuitions of public policy, avowed or unconscious"23 to be the standards by which every law is determined. These standards are communal and objective. Standards that are, by contrast, personal and subjective, such as those of an Austinian sovereign, Holmes calls "moral."

Throughout The Common Law Holmes reiterates the opposition of internal, moral standards of conduct and external, objective standards of conduct:

[W] hile the terminology of morals is still retained, and while the law does still and always, in a certain sense, measure legal liability by moral standards, it nevertheless, by the very necessity of its nature, is continually transmuting those moral standards into external or objective ones, from which the actual guilt of the party concerned is wholly eliminated. ${ }^{24}$

Here and elsewhere Holmes identifies "internal" with "moral," and "external" with "objective." 25 Thus internal standards, for Holmes, are psychological and subjective, and they grade the personal moral culpability of a particular individual. External standards are public and grade the conduct of the members of the community generally.

Holmes's insistence that legal rules are external implies that legal terms such as "intent" and "malice" require public criteria for their application. Legal liability, for Holmes, can only be imposed by rules that are shared by members of the community. Moral blame, on the other hand, can be ascribed to a person by applying rules that are private and internal; that is, in Holmes's view moral terms such as "blameworthy" and "actual guilt" do not require public, shared criteria for their application. The law may often appropriate a subjective moral term, but once appropriated, the moral term loses its private standards of application and comes to be applied by public, shared standards: "[T]he tendency of the law everywhere is to transcend moral and reach external standards. . .."26

Holmes's theory of external legal standards is illustrated in his treat-

23. HoLMes 5 .

24. Id. at 33 .

25. See $i d$. at 43: "[T] $]$ he tests of liability are external, and independent of the degree of evil in the particular person's motives or intentions." See id. at 7-8, 35, 41-42, 88 .

26. Id. at 107-08. 
ment of the element of malice in the crime of murder. ${ }^{27}$ Holmes notes that malice, as used in common speech, is a word of moral condemnation. When a person is said to act maliciously, it is commonly meant both that the person acts intentionally, and that the person wishes to cause harm or suffering for its own sake. Between these two parts of malice, only intent is relevant to the crime of murder; one may murder another, according to Holmes, and yet be sorry that the other suffers and dies. The legal use of malice thus lacks moral connotations: "Malice, in the definition of murder, has not the same meaning as in common speech, and, in view of the considerations just mentioned, it has been thought to mean criminal intention." 28

With malice thus reduced to criminal intent, Holmes suggests that criminal intent requires two elements: first, foresight that particular results will flow from a particular act, and second, desire that the results foreseen shall occur. ${ }^{29}$ Holmes shows that, in fact, the second element is superfluous:

For instance, a newly born child is laid naked out of doors, where it must perish as a matter of course. This is none the less murder, that the guilty party would have been very glad to have a stranger find the child and save it. ${ }^{30}$

Thus foresight that death will result from a particular act is enough to constitute criminal intent in murder, whether or not the guilty party desired the death.

A person is guilty of murder if he acts so as to kill another in a situation where such a result is likely to occur, whether or not he actually foresaw that the death of another would result from his actions: "The test of foresight is not what this very criminal foresaw, but what a man of reasonable prudence would have foreseen." $31 \mathrm{Al}$. though to have legal intent a person must know the circumstances making a particular action dangerous to life, persons are held to reasonable prudence in discovering such circumstances. ${ }^{32}$

The example given by Holmes is of a workman on a housetop throwing a beam down to the ground. ${ }^{33}$ If the workman knows there to be

27. Holmes uses Sir James Stephen's definition of murder as unlawful homicide with malice aforethought. Id. at $43-44$.

28. Id. at 45 .

29. Id.

30. Id.

31. Id. Thus Holmes rejects mens rea. See id. at 61: "[T]he mens rea, or actual wickedness of the party, is wholly unnecessary." Holmes has not, however, adopted strict liability for murder, because the element of intent is still central to his account. See Allen, Criminal Law, 31 U. CHI. L. Rev. 257, 260 (1964).

32. Holmes 46.

33. Id. at 47 . 
a busy street below, he must understand at his peril that to drop the beam will likely cause serious injury or death. If he does drop the beam and kills a passerby, he is charged with murder, regardless of whether he in fact understood the consequences of his dropping the beam. If the workman knows the space below to be a dump-heap shut off from intruders, a death caused by a beam dropped by the workman is not murder. Whether a death so caused is murder, manslaughter, or mere misadventure is determined by the foreseeable risk to passersby from the falling beam. ${ }^{34}$

An intentional killing may be reduced from murder to manslaughter if the defendant acted after sufficient provocation. According to Holmes this is not because the provocation left the crime in effect unintentional. In these situations, the defendant is unable to control himself and is beyond the influence of threatened punishment; to the extent the defendant cannot control himself his actual mental constitution at the time of the crime is taken into account by the law. Yet the circumstances in which persons are excused because the law's threats carry no force are determined largely by objective standards. The sufficiency of provocation has been decided by such tests as the length of time between provocation and killing, and the nature of the weapon used to kill. ${ }^{35}$

On Holmes's account the element of malice in the crime of murder is reduced first to intent and then to knowledge of circumstances making a particular act dangerous to human life. The moral connotation of malice is drained off and what remains is the objective element of knowledge of certain circumstances. The inferences to be drawn from this knowledge are those common experience has shown to be warranted, and these inferences are presumed to have been drawn. Except in exceptional cases a failure to foresee the consequences of an action is no defense.

Holmes applies his theory of external legal standards across the entire sweep of The Common Law. Holmes's attempt to bring the bases of legal liability into a "philosophically continuous series"36 rests on the attack, implicit throughout The Common Law, on the notion that private, internal standards can serve as a basis of legal liability. Howe explains Holmes's theory of external standards as an attempt to increase the certainty and predictability of the law, because ex-

34. Id.

35. See id. at 51: "At the same time the objective nature of legal standards is shown even here... There must be provocation sufficient to justify the passion, and the law decides on general considerations what provocations are sufficient."

36. Id. at 104 . 
ternal, public standards can be applied in a precise and regular fashion. ${ }^{37}$ This is accurate, but it is important to recognize that the crux of Holmes's theory is that private, internal standards cannot be applied in precise and regular fashion..$^{38}$ Holmes saw that only external, public standards can function as standards at all.

Holmes's recognition that only public standards can function as legal rules is paralleled in Charles Peirce's attack on the epistemology of Rene Descartes. ${ }^{39}$ In two articles published in 1868, "Concerning Certain Faculties Claimed For Man," 40 and "Some Consequences of Four Incapacities," 41 Peirce argued that the Cartesian use of the individual consciousness as the ultimate criterion of truth and falsehood is wrong in principle. Descartes held that the individual's clear and distinct intuition is the surest gauge of truth. Peirce says that this amounts to asserting that "[w]hatever I am clearly convinced of, is true." $¥ 2 \mathrm{He}$ goes on: "[T]hus to make single individuals absolute judges of truth is most pernicious." $\$ 3$ Peirce in fact denies that persons have a power of introspection that gives direct knowledge of the contents of consciousness; rather, "all knowledge of the internal world is derived by hypothetical reasoning from our knowledge of external facts." 44

Peirce's substitute for the Cartesian clear and distinct idea is the agreement of a community of inquirers:

In sciences in which men come to agreement, when a theory has been broached it is considered to be on probation until this agreement is reached. After it is reached, the question of certainty becomes an idle one, because there is no one left who doubts it. We individually cannot reasonably hope to attain the ultimate philosophy which we pursue; we can only seek it, there-

37. 2 Howe, supra note 1, at 197. Francis Allen rejects Howe's explanation. Allen, supra note 31 , at 261 .

38. Holmes's arguments in The Common Law are structured such that this negative thesis, that private rules are incapable of precise, regular application, is never explicitly made. Holmes expends great effort showing that external legal standards can account for the law's use of psychological terms such as "intent" and "malice," and his arguments to this end imply that internal standards cannot account for the law's use of these terms. Holmes gives no other reason for rejecting internal standards. It is important that Holmes is examining the bases of liability at common law, and not merely the evidentiary advantages of legal rules that deal purely with conduct. See Holmes 105 (discussion of intent). Although The Common Law is cast in historical form, Holmes's arguments for his theory of external legal standards are logical and not historical. See 2 HowE, supra note 1 , at $161-62$.

39. For a description of Descartes's philosophy, see A. Kenny, Descartes (1968).

40. PeIrce f 5.213, originally published in 2 J. Speculative Phil. 103 (1868).

41. Peirce If 5.264, originally published in 2 J. Speculative Phil. 140 (1868).

42. Peirce if 5.265.

43. Id.

44. Id. ๆ 5.265. For Peirce's arguments against introspection, see id. II $5.244-249$. 
fore, for the community of philosophers. Hence, if disciplined and candid minds carefully examine a theory and refuse to accept it, this ought to create doubts in the mind of the author of the theory himself. 45

Descartes's paradigm of knowledge was geometry; Peirce's paradigm was the experimental or laboratory sciences. ${ }^{46}$ Peirce sought to replace Descartes's reliance on the "natural light" of immediate intuition of clear and distinct ideas with the process of a community of inquirers reaching agreement through application of public and accepted methods of research. The community of inquirers following scientific method is defined, as Professor John Smith has said, "by the willingness of each individual member to sacrifice what is personal and private to him alone in order to follow the dictates of an interpersonal method that involves free exchange of views and results." 17

In his 1878 article, "How To Make Our Ideas Clear," Peirce first formulated his celebrated "pragmatic maxim":

[C]onsider what effects, that might conceivably have practical bearings, we conceive the object of our conception to have. Then, our conception of these effects is the whole of our conception of the object. ${ }^{48}$

This maxim was designed to achieve the third degree of clarity in our ideas, after the degrees of familiarity and definition. ${ }^{40}$ It carries two significant implications: first, it implies that the meaning of words (or of ideas) is given in sets of rules that are public and communal; second, it implies that meaning is dependent upon possible future

45. Id. I 5.265 (Peirce's emphasis).

46. Holmes shared Peirce's paradigm. For Holmes's assertion that science was "at the bottom" of the gap between Holmes and his father, see Holmes-CoHEN Correspondence, supra note 10, at 14 (letter of Feb. 5, 1919).

Howe offers this description of Holmes's reading as a law student and young practitioner:

Suffice it to say that Holmes's readings outside the law clearly indicate his absorption in the philosophical problems of the time. In the broadest sense those problems turned upon the central impact of science upon belief-upon the question whether the positivist methods of science were to displace the metaphysical methods of the philosophers.

Howe, supra note 8 , at 7. But cf. 2 Howe, supra note 1 , at 75 .

47. J. Smith, Themes in American Philosophy 98 (1970).

48. PEIRCE $\int$ 5.402. This maxim has any number of other formulations in Peirce's philosophy, e.g., "[I]f one can define accurately all the conceivable experimental phenomena which the affirmation or denial of a concept could imply, one will have therein a complete definition of the concept, and there is absolutely nothing else in it." Id. If $\mathbf{5 . 4 1 2}$ (Peirce's emphasis). For discussions of Peirce's maxim, see H. ThaYer, supra note 11, at 85-86; C. Morris, The Pragmatic Movement in American Philosophy 20-23 (1970). 49. Peirce says the maxim leads to "more perfect clearness of thought, such as we see and admire in the thinkers of our own time." PEIRCE $\mathbb{5} .390$. 
events, and therefore that the meaning of a word is conditional upon the shape of future events.

The public nature of meaning analyzed with the pragmatic maxim may be illustrated by an example used by Peirce, that of the word "hard." 50 By calling a thing hard it is meant, according to Peirce, that the thing can be scratched by only a few materials. The meaning of "The steel plate is hard" is a rule that the steel plate will not be scratched if rubbed with wood, or cork, or most plastics, etc.

Peirce's example will also serve to illustrate the second implication of the pragmatic theory of meaning. If "hard" means "If rubbed with wood (or cork, or plastic), this material will not be scratched," then the meaning of "hard" is contained in a rule telling us what to expect in the future from certain actions. Told that a lump of quartz is hard, we will not expect it to be scratched by wood or cork; given the meaning of a word, we may predict the outcome of our operations on the object to which the word is applied.

Peirce says, "Man is so completely hemmed in by the bounds of his possible practical experience ... that he cannot, in the least, mean anything that transcends those limits." ${ }^{51}$ In other words, it is not possible to make meaningful assertions that do not have at least a possible practical bearing on our future conduct; a conception to be meaningful must have practical consequences of some kind. This shows why Peirce held that rules must be public and communal: Given that we lack a power of introspection, the limits of the shared world are the limits of our practical experience. Private rules, known through introspection, are impossible; the only meaningful rules are public and communal.

Holmes and Peirce both contrasted public, external rules with private, internal rules. For Holmes, external standards govern imposition of liability in crime, tort, and contract. For Peirce, external rules govern the search for truth and the meaning of words. Holmes's attack on legal standards that are private and internal is simply another version of Peirce's attack on the Cartesian clear and distinct idea as a criterion of truth. When Holmes demands that legal standards be public and external, he is responding to the same philosophical impulse that led Peirce to say that all knowledge of our psychological states is derived from observation of public facts.

Holmes's theory of external legal standards is ambivalent on the relation of law to morality. Giving moral standards only private ap-

50. Id. โ 5.403 .

51. Id. \5.536. See id. \ 5.412. 
Holmes, Peirce and Legal Pragmatism

plication while giving legal standards only public application makes moral standards and legal standards mutually exclusive. Despite this, Holmes wants to "measure" legal liability by moral standards "in a certain sense." He also wants moral standards "transcended" or "transmuted" into external (and hence nonmoral) standards. ${ }^{52}$ Nowhere in The Common Law does Holmes describe the "certain sense" in which law and morals are related, and he leaves the manner in which morals are "transmuted" obscure. Holmes separates legal standards and moral standards in a way that makes any relationship between the two impossible, and thus his attempts to explain their relation are inadequate and unclear.

Holmes could have avoided this ambivalence had he carried his attack on private standards to its logical conclusion, as Peirce carried his attack on Descartes. The philosophical impulse that pushed Holmes to demand that legal standards be public and external was a recognition, implicit throughout The Common Law, that it is impossible to give a coherent account of a legal standard that is private to an individual, and not part of the public, shared world. ${ }^{53}$ Yet Holmes's analysis of legal rules should apply as well to moral rules: both the rules by which we impose legal liability and the rules by which we impose moral blame must be part of the public, shared world. In attacking Descartes, Peirce showed that any rule-moral, legal, or scientific-must be communal to be meaningful.

If Holmes had followed Peirce and treated both moral standards and legal standards as external and public, then his ambivalence could have been resolved. Holmes may have feared that to grant moral standards the same status as legal standards would have forced an assimilation of law and morality, but this fear is groundless: legal standards and moral standards may both be external without implying that legal rules must impose liability only on the basis of moral culpability. ${ }^{54}$ Allowing legal standards and moral standards to be external would have made intelligible Holmes's claim that the two are related: "[C]riminal liability, as well as civil, is founded on blameworthiness. ... [A] law which punished conduct which would not be blameworthy in the average member of the community would be too severe for that community to bear."

52. See p. 1127 supra.

53. See note 38 supra; L. Wittgenstein, Philosophical Investigations 153 (1953): “An 'inner process' stands in need of outward criteria."

54. See L. Fuller, The LAw IN Quest of Itself 5 (1940). For Howe's defense of Holmes against Fuller's charge of positivism, see Howe, The Positivism of Mr. Justice Holmes, 64 HaRv. L. REv. 529 (1951).

55. Holmes 42. 
Holmes's failure to resolve this ambivalence caused him to give a fundamentally impoverished account of law..$^{56}$ Holmes asserts in a famous passage that the "first requirement" of a sound body of law is that it reflect the needs and desires of the community, whether right or wrong. ${ }^{57}$ Perhaps this is true, but certainly the second requirement is that law be fair and just. Holmes never requires fairness and justice of law because he cannot describe the relation of these moral notions to his "objective" legal rules. Had Holmes not drawn the line between law and morality where he did, his account of law would have been less stark, and it would have encompassed the moral demands we make of law.

\section{The Community as Arbiter of Standards in Holmes and Peirce}

The second fundamental parallel between The Common Law and Peirce's early philosophy is the recognition that the community is the important arbiter of standards. Their rejection of internal standards flows from a desire for objectivity, and both understood that objectivity could only result from agreement among members of a community. In Peirce's case the relevant community is composed of scientific inquirers: in Holmes's it is the group of citizens subject to law. ${ }^{58}$

The role of the community in Holmes's theory is shown most clearly in his treatment of the jury in negligence cases. ${ }^{59}$ The jury's function, according to Holmes, is to find a rule of conduct based on practical experience:

[A]s the teachings of experience are matters of fact, it is easy to see why the jury should be consulted with regard to them. They are, however, facts of special and peculiar function .... Their function is to suggest a rule of conduct. ${ }^{80}$

56. See Rogat, The Judge as Spectator, 31 U. Chr. L. Rev. 213, 225 (1964).

57. Holmes 36.

58. Strictly, in Holmes's case the relevant community is that of judges and jurors, since together they formulate and apply law. The citizens subject to law possess a veto over laws that are too harsh.

59. Id. at 97-103. Jerome Frank argues that Holmes's account of the jury was taken "unconsciously" from Green's essay, Proximate Cause and Remote Cause, reprinted in N. GRFEN, supra note 9, at 1. See Frank, supra note 9, at 434-37. While Green certainly influenced Holmes, Green's essay presents a purely legal analysis of the jury's function in negligence cases. Frank does not explain the origin of the remarkable ideas that suggested this account of the jury's function. Compare Green, Slander and Libel, in $\mathbf{N}$. GREEN, supra note 9 , at 49 , with HoLMEs 110-12.

60. HOLMES 119-20. 
The judge, an individual, can formulate rules of conduct, but unless guided by the jury, he cannot correct mistaken rules. ${ }^{61}$ Holmes says, "The first requirement of a sound body of law is, that it should correspond with the actual feelings and demands of the community, whether right or wrong." ${ }^{2}$ The individual judge might lay down a just rule of conduct that for Holmes would be unsound because it failed to reflect the desires of the community.

Holmes notes that the question of negligence has two parts: first, that the defendant has done or failed to do certain acts; and second, that his conduct does not meet the legal standard of care. ${ }^{83}$ The first part will always be the responsibility of the jury. The second part will fall to either the court or the jury depending on whether the court feels competent to lay down a rule of liability without consulting the jury's practical experience. Even in cases where the court presently feels incompetent, it eventually should begin to articulate and apply a rule by itself, at least in situations that repeatedly present themselves:

Either the court will find the fair teaching of experience is that the conduct complained of usually is or is not blameworthy, and therefore, unless explained, is or is not a ground of liability; or it will find the jury oscillating to and fro, and will see the necessity of making up its mind for itself. ${ }^{64}$

Over an indefinite period of time the court's practical knowledge should expand to the point where it is no longer necessary to consult the jury when selecting a rule of liability.

Peirce gives an account of scientific inquiry that is logically parallel to Holmes's account of the jury's function. For Peirce, if we desire a certain result from our actions, it is necessary to act according to rules that enable us to predict the results of particular acts. Peirce calls these rules of conduct "habits," 65 and equates them with beliefs: "The feeling of believing is a more or less sure indication of

61. See id. at 98: "[T]he court...f feels that it is not itself possessed of sufficient practical experience to lay down the rule intelligently. It conceives that twelve men taken from the practical part of the community can aid its judgment."

62. Id. at 36 .

63. Id. at 97 .

64. Id. at 98. See id. at 99: "A judge who has long sat at nisi prius ought gradually to acquire a fund of experience which enables him to represent the common sense of the community in ordinary instances far better than an average jury.... Furthermore, the sphere in which he is able to rule without taking their opinion at all should be continually growing."

65. Peirce no doubt took his use of "habit" from the scholastic philosophers, who used it to denote dispositions to act in particular ways. See Fisch, supra note 20, at 420 n.29. 
there being established in our nature some habit which will determine our actions." 66 Peirce thought that everyone of necessity relies on a wide range of habits in day-to-day life.

Inquiry begins when a previously accepted habit fails in a specific instance to produce the expected results. This failure causes the validity of the habit to be doubted, and the doubt cannot be dispelled until belief in a new habit is established. Doubt is an "uneasy and dissatisfied state" that drives us to conduct inquiry into the ability of possible new habits to predict accurately the outcome of particular acts. ${ }^{67}$ Peirce holds that the "sole object of inquiry is the settlement of opinion." 88 It is not the case that inquiry seeks truth; it seeks only firm belief, because once belief in a habit is firmly held the habit is no longer questioned. ${ }^{69}$

In "The Fixation of Belief" Peirce discusses several methods of settling opinion, but he argues that the only adequate method is that of science. The advantage of scientific method is that it is self-corrective: The hypotheses we draw from observations will ultimately be free of error, according to Peirce. Yet given that inquiry seeks only firm belief, it is difficult to understand why the result of scientific inquiry is the ultimate correction of all error. Peirce explains that, while the individual seeks only firm belief, the result of the community's inquiry, carried out over an indefinitely long period, is the correction of all error:

All that we can know or conceive of the existence of real things is involved in two premises: First, that investigation will ultimately lead to a settled opinion, and, second, that this opinion is entirely determined by observations. The only thing that we can infer is that the observations have such a character that they are fated to lead ultimately to one conclusion. ${ }^{70}$

66. PeIrCE โ 5.371 .

67. Id. \ 5.372. This "doubt/belief" theory of inquiry was derived from the writings of the Scottish psychologist, Alexander Bain. Like Peirce, Bain discusses beliefs as dispositions to act in certain ways. The members of the Metaphysical Club were all familiar with Bain's work; Holmes cites Bain's Mental and Moral Science in the first chapter of The Common Law. Holmes 13 n.25. See Fisch, supra note 20 (a discussion of Bain's influence on pragmatism).

Holmes met Bain in London in 1866 and remarked in his diary that while Bain had an impressive knowledge of fact, he lacked the "infinite perspective of metaphysics." Quoted in P. WIENER, supra note 9, at $269 \mathrm{n} .16$.

68. Peirce fi 5.375. He continues: "We may fancy that this is not enough for us, and that we seek, not merely an opinion, but a true opinion. But put this fancy to the test, and it proves groundless; for as soon as a firm belief is reached we are entirely satisfied, whether the belief be true or false." Id.

69. Peirce's view of this matter is complex and he modified his position over a period of years. See Bronstein, Inquiry and Meaning, in Studies IN THE PHILOsophy of Charles SANDERs Peirce, supra note 11 , at 33.

70. Quoted in M. Murphey, The Develorment of Peirce's Philosophy 166 (1961). 
Holmes, Peirce and Legal Pragmatism

This ultimate conclusion would be the truth. Thus, Peirce tries to define truth in terms of inquiry, and inquiry in terms of doubt and belief.

The community plays a similar role in Holmes's account of the jury's function and in Peirce's theory of scientific inquiry. Just as Peirce ties together truth and the firm beliefs of the community, Holmes identifies the soundness of a law with its relation to the desires of the community. In both accounts, the community serves to correct the errors of individuals.

III. The Indefinite Continuation of Adjudication and Inquiry

The final parallel between The Common Law and Peirce's early philosophy is that both postulate an indefinite continuation of the processes they describe. In the opening lecture of The Common Law Holmes says:

The truth is, that the law is always approaching, and never reaching, consistency. It is forever adopting new principles from life at one end, and it always retains old ones from history at the other, which have not yet been absorbed or sloughed off. It will become entirely consistent only when it ceases to grow. ${ }^{71}$

The law's consistency comes from the logical form of its development, each decision following logically from precedent. The substance of the law, however, is legislative, Holmes says. ${ }^{72}$ When precedent in negligence law calls for one rule, and changed circumstances cause judges and juries to think only another rule fair to plaintiffs and defendants, then precedent will be reasoned away.

The official theory is that each new decision follows syllogistically from existing precedents. But just as the clavicle in the cat only tells of the existence of some earlier creature to which a collarbone was useful, precedents survive in the law long after the use they once served is at an end and the reason for them has been forgotten. The result of following them must often be failure and confusion from the merely logical point of view. ${ }^{73}$

71. Holmes 32 .

72. See id. at 5,32 .

73. Id. at 31. Grant Gilmore has described the "official theory" Holmes was reacting against:

[L]aw was a symmetrical structure of logical propositions, all neatly dovetailed.

The truth or error, the rightness or wrongness, of a judicial decision could be 
The adoption of new rules, or new rationales for old rules, blocks consistency in the law, even though consistency is demanded by legal form; this is the "paradox of form and substance in the development of the law." "Holmes reconciles the demands of logic and legislation by postulating an indefinite continuation of the legal process: the law will constantly approach, and never reach, consistency.

Holmes's resolution of this paradox is logically similar to Peirce's solution of the problem set by his assertion that scientific method is self-corrective. Scientific method can be self-corrective only if some changes in scientific theory are corrections rather than mere changes in belief; yet this seems difficult if inquiry seeks only firm belief. Peirce's distinction between the immediate goal of the individual (firm belief) and the ultimate goal of the community (truth) avoids the Cartesian conclusion that truth is whatever is believed, but it presents Peirce with the need to explain why the ultimate belief shared by the community is truth..$^{75}$

Peirce's explanation is that scientific method is "fated" to lead ultimately to a single true opinion. Peirce says he does not mean anything superstitious or occult by "fate," only that which is certain to happen, as in "We are all fated to die."70 Peirce has two reasons for concluding that scientific inquiry is destined ultimately to lead to the truth: first, the history of science reveals that persistent inquiry into a problem eventually results in a stable community belief; second, Peirce's metaphysic describes a universe evolving toward rationality and order, which suggests that in the long run all scientific questions will be answered. ${ }^{77}$

Peirce's assertion that firm belief and scientific observations are ultimately fated to coincide is less startling when taken in the context of Peirce's expectation that scientific inquiry will never cease. Just as Holmes avoids a clash between the logical and legislative sides of the law by tolerating the "paradox" of inconsistency as a product of

determined by merely checking to sec whether it fitted into the symmetrical structure; if it fitted, it was right; if it did not fit, it was wrong and could, or at lcast should, be disregarded.

Gilmore, Legal Realism: Its Causes and Cure, 70 YaLE L.J. 1037, 1038 (1961).

74. Holmes 31 .

75. See Bronstein, supra note 69 , at 38 .

76. Thayer has remarked that Peirce's use of "fate" "seems to attribute an occult power to true opinions and a mysterious efficacy to truth." H. THAYER, supra note 11, at 125. See J. SMIrH, supra note 47, at 99-102. Although Peirce did not always use "fate," his statements invariably rely on similar conceptions: "Truth is that concordance of an abstract statement with the ideal limit toward which endless investigation would tend to bring scientific belief...." PEIRCE If 5.565. (Peirce's style sometimes obscures his thoughts rather than illuminating them.)

77. See J. SMIrH, supra note 47, at 99-100. 
Holmes, Peirce and Legal Pragmatism

legal change, Peirce pushes his reliance on fate to one side by postulating an indefinite continuation of scientific inquiry. Where Peirce asserts the community will constantly approach truth, Holmes asserts that the law will constantly approach consistency.

\section{Conclusion}

In his lecture on the criminal law, Holmes wrote:

[I]t seems to me clear that the ultima ratio, not only regum, but of private persons is force, and that at the bottom of all private relations, however tempered by sympathy and all the social feelings, is a justifiable self-preference. ${ }^{78}$

Howe notes that such "Darwinian premises" as expressed here by Holmes usually led to political philosophies built around the rights and powers of individuals. Howe goes on to say:

In Holmes's case, however, his recognition that the common law had persistently worked its way toward objective standards of liability brought with it ... an acknowledgment that the tendency if not the progress of civilization is toward the preference of social to private interests. ${ }^{79}$

Often Holmes did think (and decide, after he gained the bench) that the needs of society have first claim on the individual..$^{80}$ Yet consider how extraordinarily against the grain of the late 19th century Holmes's thought went. Not only did Darwinian and Spencerian premises place the individual ahead of society, but jurisprudence and philosophy invariably focused on the individual.

Holmes's early efforts in jurisprudence were directed against John Austin. Austin's description of the sovereign as completely independent, with a will utterly unbounded is a description of a Cartesian consciousness. The sovereign relies on private standards for giving his commands to his subjects. Holmes's attack on Austin's theory is directed at the notion that the sovereign's standards could be, even in principle, private and internal. Holmes built his theory of legal standards on the idea that objectivity can be gained only through intersubjective agreement among members of a community.

78. HoLMes 38 .

79. Howe, supra note 3 , at xxvi.

80. See Lowry, Mr. Justice Holmes: The Community vs. The Individual, 36 CaLIF. L. REv. 390 (1948). 
Thus Holmes's preference of social over individual interests results from his demand for objective legal standards, in much the same way that Peirce's attack on Descartes led him to demand agreement among a community of inquirers as a measure of truth. Just as Holmes argued that the sovereign is hemmed in by "considerations of what is expedient for the community concerned," 81 Peirce argued that the individual inquirer must sacrifice his private goals and standards to the community's interpersonal scientific method. Both men shared the central perception that individual standards are inherently subjective, and that a community is necessary for objectivity.

Perhaps it is worth recalling that Holmes and Peirce were both members of the Metaphysical Club where Peirce read his paper, "expressing some of the opinions that I had been urging all along under the name of pragmatism."'s2 The fundamental parallels between The Common Law and Peirce's early philosophy are striking, and they suggest that Peirce may have been a more important direct influence on Holmes than has been recognized or than Holmes admitted. ${ }^{83}$

81. Holmes 32.

82. PeIrce II 5.12-.13.

83. See note 20 supra. 